Portland State University

PDXScholar

$12-2015$

\title{
Comparative Estimates of Anthropogenic Heat Emission in Relation to Surface Energy Balance of a Subtropical Urban Neighborhood
}

\author{
Changhyoun Park \\ Pusan National University \\ Gunnar W. Schade \\ Texas A\&M University \\ Nicholas D. Werner \\ Texas A\&M University \\ David J. Sailor \\ Portland State University, sailor@pdx.edu \\ Cheol-Hee Kim \\ Pusan National University
}

Follow this and additional works at: https://pdxscholar.library.pdx.edu/mengin_fac

Part of the Materials Science and Engineering Commons, and the Mechanical Engineering Commons Let us know how access to this document benefits you.

\section{Citation Details}

Park, C., Schade, G.W., Werner, N.D., Sailor, D.J., Kim, C.-H., Comparative estimates of anthropogenic heat emission in relation to surface energy balance of a subtropical urban neighborhood, Atmospheric Environment (2015).

This Post-Print is brought to you for free and open access. It has been accepted for inclusion in Mechanical and Materials Engineering Faculty Publications and Presentations by an authorized administrator of PDXScholar. Please contact us if we can make this document more accessible: pdxscholar@pdx.edu. 


\section{Comparative estimates of anthropogenic heat emission in relation to}

2 surface energy balance of a subtropical urban neighborhood

3

\section{Changhyoun Park ${ }^{1}$, Gunnar W. Schade ${ }^{2}$, Nicholas D. Werner ${ }^{2}$, David J. Sailor ${ }^{3}$, and Cheol-Hee Kim ${ }^{4}$}

1. Institute of Environmental Studies, Pusan National University, Busan, 46241, South Korea

2. Department of Atmospheric Sciences, Texas A\&M University, 3150 TAMU, College Station, TX 77843, USA

3. Department of Mechanical and Materials Engineering, Portland State University, Portland, OR 97207, USA

4. Department of Atmospheric Environmental Sciences, Pusan National University, Busan, 46241, South Korea

\footnotetext{
* Corresponding author, Tel.: 1979845 0633; fax: 19798624466.
}

E-mail address: gws@geos.tamu.edu (G.W. Schade)

\section{Highlights}

- Two-year flux measurements were conducted in a subtropical urban area.

- Heat emissions were estimated by residual method and inventory approach.

- A new 'footprint-weighted inventory' approach was introduced.

- Local missing anthropogenic heat sources were partially revealed.

\section{Abstract}

Long-term eddy covariance measurements have been conducted in a subtropical urban area, an older neighborhood north of downtown Houston. The measured net radiation $\left(Q^{*}\right)$, sensible heat flux $(\mathrm{H})$ and latent heat flux (LE) showed typical seasonal diurnal variations in urban areas: highest in summer; lowest in winter. From an analysis of a subset of the first two years of measurements, we find that approximately $42 \%$ of $Q^{*}$ is converted into $\mathrm{H}$, and $22 \%$ into $\mathrm{LE}$ during daytime. The local anthropogenic heat emissions were estimated conventionally using the long-term residual method and the heat emission inventory approach. We also developed a footprint-weighted inventory approach, which combines the inventory approach with flux footprint calculations. The results show a range of annual anthropogenic heat fluxes from $20 \mathrm{~W} \mathrm{~m}^{-2}$ to $30 \mathrm{~W}$ $\mathrm{m}^{-2}$ within the study domain. Possibly as a result of local radiation versus heat flux footprint mismatches, the mean value of surface heat storage $(\Delta Q s)$ was relatively large, approximately $43 \%$ and $34 \%$ of $Q^{*}$ in summer and winter, respectively, during daytime. 


\section{Introduction}

Approximately half of the world's population lives in and develops urban areas, modifying land use and land cover (LULC), and consuming energy and producing byproducts like waste heat, water vapor and pollutants. This results in the urban heat island (UHI) effect, and affects planetary boundary layer depth, air pollution and precipitation over urban areas (Arnfield, 2003). The man-made, urban fabric alters the surface energy balance (SEB) alongside atmospheric winds, temperature, moisture and chemical composition (Grimmond and Oke, 1999; Roth, 2007).

Urban energy balance studies have been conducted by direct measurements of $Q^{*}$ using radiometers, alongside sensible and latent heat fluxes using the eddy covariance (EC) technique (e.g., Rotach 2005; Offerle et al., 2005; Ferreira et al., 2013; and Nordbo et al., 2012). In urban areas, typically a large amount of surface heat energy is transferred to the atmosphere as sensible heat, while the amount of latent heat transfer is lower than over forests or agricultural areas. This is due to the facts that urban impervious area reduces (i) available surface water for evaporation, and (ii) vegetation amount and therefore leaf area index (LAI) over that in natural area. Consequently the Bowen ratio $(\beta=\mathrm{H} / \mathrm{LE})$ is larger above urban canopies, yet generally its value can be much different locally depending on urban surface heterogeneity.

Most past SEB studies have been performed in cities located in the mid-latitudes (e.g. Moriwaki and Kanda, 2004; Vesala et al., 2008; and Kotthaus and Grimmond, 2013), and fewer in tropical or subtropical cities. Considering the size and fast growth of subtropical cities without well-organized city planning or land use, studies of SEB in subtropical cities are important for sustainable development (Roth, 2007). Few studies of (sub)tropical urban SEB have been conducted as summarized by Roth (2007), yet only one long-term (> 1yr) study (Ferreira et al., 2011) has been conducted to estimate the annual features of SEB in a unique urban area.

Anthropogenic heat emissions can strongly affect the urban SEB, which can be estimated using the urban SEB equation expressed for a particular urban area considered homogeneous for the purposes of the evaluation (Oke, 1988):

$$
Q^{*}+Q_{f}=\mathrm{H}+\mathrm{LE}+\Delta Q s+\Delta Q_{a} \quad\left(\text { Unit: } \mathrm{W} \mathrm{m}^{-2}\right)
$$

$Q^{*}$ is net all-wave radiation; $Q_{f}$ is anthropogenic heat flux from buildings, transportation and human metabolism (Sailor, 2011; Iamarino et al., 2012); H is turbulent sensible heat flux; LE is turbulent latent heat flux; and $\Delta Q s$ is net storage of heat in the urban fabric, including buildings, roads, trees, soils, etc. $\Delta Q_{a}$ is net advective flux, and it is typically presumed negligible if the flux instrumentation is installed above an urban area homogeneous on larger scales, thus minimizing $\Delta Q_{a}$.

Heat storage, $\triangle Q s$, is significant in urban areas, and can represent a relatively large fraction of $Q^{*}$. There is no one method to measure $\Delta Q s$ directly in urban areas because of the wide variety of lightabsorbing and heterogeneously distributed urban canopy structures and ground surfaces. However, several integral methods have been introduced: the SEB residual method (Grimmond and Oke, 1995; Kothaus and Grimmond, 2013; Ferreira et al., 2013; Nordbo et al., 2012), the Objective Hysteresis Modeling (OHM) method (Grimmond and Oke, 1999; Ferreira et al., 2013), and the parameterization method (Roberts et al., 
Anthropogenic heat fluxes, $Q_{f}$, are also difficult to measure, so have generally been estimated via either an inventory-based or energy balance closure approach. Depending on a study's objective, inventory approaches either use large scale aggregated data that are downscaled to smaller spatiotemporal units (e.g. local and hourly), or use energy consumption data estimated at smaller, building and road section scales for upscaling. The former is conducted based on utility energy consumption and empirical traffic count data (e.g., Sailor and Lu, 2004; Iamarino et al., 2012; Chow et al., 2014). The latter uses building energy modeling and can resolve the anthropogenic heating from complicated building sectors (Kikegawa et al., 2006; Hsieh et al., 2007). Both typically assume that the total energy consumption converts to waste heat emissions, i.e. materialize dominantly in the sensible heat flux; but contributions to heat storage and even latent heat fluxes are also possible.

Alternative to the inventory approach, using long-term micrometeorological measurements can enable estimates of anthropogenic heating as the residual term in the SEB equation (1) under the assumption that $\Sigma \Delta Q s$ equals zero over year-long periods (Christen and Vogt, 2004; Ferreira et al., 2013; Nordbo et al., 2012). Offerle et al. (2005) calculated $\Delta Q s$ with an element surface temperature method to determine $Q_{f}$ (hereafter called Res-driven $Q_{f}$ ).

The residual energy flux (Res) is considered as follows given $\Delta Q_{a}$ is negligible (e.g. Nordbo et al., 2012):

$$
\operatorname{Res} \approx \Delta Q s-Q_{f}=Q^{*}-(\mathrm{H}+\mathrm{LE})
$$

In equation (2), negative Res means that there are additional energy sources contributing to $\mathrm{H}$ and $\mathrm{LE}$ aside from net radiation, particularly anthropogenic heat flux. For longer periods (complete seasonal cycle or multiples thereof), $\sum \Delta Q s=0$, so the residual term can be representative of $Q_{f}$. The negative sign indicates the emission from the surface to the atmosphere. The uncertainty of this approach comes not only from the accumulation of errors in the measurements of $\mathrm{H}, \mathrm{LE}$, and $Q^{*}$ into Res, resulting in $Q_{f}$ uncertainties up to 20$40 \%$ of $Q^{*}$ (Mauder et al., 2007), but also from the differences between radiation and flux footprints, possibly resulting in an underestimation of $Q_{f}$ (Foken, 2008).

Here, we present an analysis of data from a unique dataset obtained over a subtropical humid urban area, Houston Texas, including an overview of the site characteristics, the micrometeorological flux measurements system, and the temporal variability of SEB fluxes. In addition, we discuss the estimates of anthropogenic heat emissions using different approaches.

\section{Methods}

\subsection{Site description}

A detailed site description of the Houston flux tower setup was given by Park et al. $(2010,2011)$ and

113 Schade (2012), and is slightly extended here. The climate of Houston is classified as subtropical humid

114 (Köppen's Climate Classification: Cfa), with rainfall in all seasons and moderate seasonal variability. The

115 radio communications tower of the Greater Houston Transportation Co. (Yellow Cab, 29 $47^{\circ}$ '22' ' N, 95 $21^{\circ}$ '

$11613^{\prime \prime} \mathrm{W}$ ) located $4 \mathrm{~km}$ north of downtown Houston was equipped with micrometeorological instrumentation

117 for urban flux measurements in late spring 2007. The site is in flat terrain (slope of less than $1 \mathrm{~m}$ per $\mathrm{km}$ ) 
118 surrounded by residential areas in south, west, and north directions, a light industrial area in the east, a park

119 and a cemetery in the more distant west, and various commuter roads crossing the area (Figure 1).Within a

$1203 \times 3 \mathrm{~km}^{2}$ area, dominant average land use is residential (23\%) and roads (23\%), while the remaining land is

121 occupied by industrial areas (12\%), commercial areas (6\%), parks and open space (17\%), public areas (1\%),

122 and undeveloped lands (18\%) (http://mycity.houstontx.gov/public/). Following Stewart and Oke (2012), the

123 site is best described as low to medium urban density with 1-2 story houses, and 50-70\% impervious area

124 with scattered trees (local climate zone, LCZ 6 B, with minor UCZ 5).

125 The average height of trees as determined from LIDAR data (at 1-ft spatial resolution, measured in

126 2008) was 8-12 m, much taller than that of one-story buildings dominating the area (4-5 m), and tree crowns

127 covered $25-30 \%$ of the study domain. We calculated displacement height $(\mathrm{d})$ and roughness length $\left(\mathrm{z}_{0}\right)$ using

128 various methods (Schade, 2009; unpublished data) and assigned area-wide $\mathrm{d}=6$ to $12 \mathrm{~m}$ and $\mathrm{z}_{0}=1.0 \pm 0.1 \mathrm{~m}$

129 for all wind directions. The directionality of $d$ is shown in the Supplemental Table S1. The relative

130 homogeneity of this site is likely owed to similarly tall one-story buildings under a sparse, but dominating

131 tree canopy. It will be discussed in a separate short communication.

132

\section{2.2. Measurement system}

134 The EC system was installed as the top inlet height ( $60 \mathrm{~m}$ above ground level (agl)), $30 \mathrm{~m}$ below the 135 top of the tower but several times higher than the height of the tallest surface roughness elements including 136 buildings and trees. A summary of installations is given in Table 1. The top level installation consisted of a 137 cross-beam holding a 3-D sonic anemometer pointing south, three radiation sensors including a thermopile, 138 a pyranometer and a quantum sensor, supplementary sensors for temperature and humidity and a combined

139 wind speed and direction sensor (Schade, 2012). Ambient air was sampled from near the center of the 140 anemometer through 1/4" ID, 80 m long Teflon PFA tubing down the tower at approximately $15 \mathrm{~L} \mathrm{~min}^{-1}$

141 and through a bypass into a closed path infrared gas analyzer (LI7000, Licor Biosciences, Lincoln, NE) in an

142 air-conditioned building at the foot of the tower. A tipping bucket rainfall sensor was installed at $12 \mathrm{~m}$ agl. A

143 PFA filter holder was installed into the main 3/8" OD sampling line at $3 \mathrm{~m}$ agl in front of a tubing bend. Its

$144 \quad 2-5 \mu \mathrm{m}$ pore size Teflon particulate filter was changed on average once a week during instrument

145 calibrations. Since this meant that the inlet was not protected from rain entering the tubing, the main sample

146 pump (rotary vane model VTE3, Thomas Pumps, Sheboygan, WI) was turned off whenever rain was

147 detected by the rain bucket, including a 20-min delay in turning the pump back on after the last bucket tip.

148 Occasionally, small amounts of water still entered the tubing as evident from residues on the filter and/or a

149 few milliliters of liquid water accumulating in the filter holder. Thus, the water vapor flux data analyzed

150 here exclude the first 24 hours after rain events.

151 A LI7000 was operated in an air conditioned room at the base of the tower. The instrument was

152 calibrated for $\mathrm{CO}_{2}$ onsite approximately weekly using a three-point calibration. Its factory $\mathrm{H}_{2} \mathrm{O}$ calibration

153 values were left unchanged during the study period, but its output was compared and adjusted against the

154 relative humidity sensor installed at the same height using its temperature data and pressure data adjusted for 155 height in the modified Buck formula used by Licor Inc.

156

157 2.3. Data processing

(C) 2015. This manuscript version is made available under the CC-BY-NC-ND 4.0 license http://creativecommons.org/licenses/by-nc-nd/4.0/ 
EC flux data were averaged over the standard 30 minute interval. Longer periods of missing or bad data occurred from mid-August to early September 2008 and from mid-October to end of November 2008, for instrument repairs. Processing of the high frequency data was conducted using EdiRe software (School of Geosciences, University of Edinburg, UK), following the general guidelines of the flux community. Random electronic noise spikes were removed from the raw turbulence data when exceeding 5 standard deviations (sd). The geometric rotation was applied to align the $\mathrm{x}$-axis with the mean wind direction and to set the 30-min average vertical wind to zero. Rotational angles were nearly always less than 5 degrees ($0.5 \pm 2.2$ degrees, $2 \mathrm{sd}$ ). Stationarity was tested by separating the 30 minute data period into six 5 -min intervals, where the flux covariance should not be biased more than $60 \%$ from the mean of the covariances of each 5-min interval (Foken and Wichura, 1996). A friction velocity threshold of $\mathrm{u}_{*} \geq 0.2 \mathrm{~m} \mathrm{~s}^{-1}$ was applied to the data to account for low turbulence conditions. The stationarity criterion $(<60 \%)$ removed $1 \%$ of the data. From periods of rain and 24 hours after rain, an additional $24 \%$ of data were removed. To assess the lag time due to the length of the sampling tube from the inlet next to the sonic anemometer to the closedpath gas analyzer, we applied the cross-correlation criterion between vertical wind speeds and mixing ratio time series data. The typical $\mathrm{CO}_{2}$ lag times ranged from 7 to 11 seconds, and the $\mathrm{H}_{2} \mathrm{O}$ lag times were typically 1 second longer. A low-pass filtering method was developed similar to that described by Ibrom et al. (2007), based on relative humidity and wind speeds (no temperature dependence was found). It was applied to our closed-path EC system for $\mathrm{H}_{2} \mathrm{O}$ flux corrections, with average LE fluxes corrected upwards by $34 \%$ (Werner, 2013).

\subsection{Footprint analysis}

In order to estimate the spatial distribution of the flux footprint, we used the analytical footprint model of Kormann and Meixner (2001) implemented in EdiRe. Although this model is not designed for heterogeneous urban surface areas and may be biased under neutral and stable atmospheric conditions, we concluded that the footprint model output should present a qualitatively correct picture of 2D surface contributions, considering the relatively homogeneous turbulence characteristics of this study site. Modeling results from Kljun's parameterization (Kljuin et al, 2004) revealed that daytime $90 \%$ footprint distances did not extend past the $3 \mathrm{~km} \times 3 \mathrm{~km}$ study domain (Figure 1). For the radiative footprint area, we used the field of view method (Schmid et al., 1991), resulting in the 90\% footprint area extending to a radius of $180 \mathrm{~m}$ (Figure 1).

\subsection{Development of a gridded anthropogenic heat emission dataset}

To obtain a local estimate of $\Delta Q_{f}$, we assembled an anthropogenic heat emission inventory (AHI) at hourly temporal and 500-m spatial resolution for Houston, Texas. The inventory presumes that all energy

192 consumption is converted into waste heat emissions. It consists of major waste heat sources in the building

193 sector, the transportation sector, and human metabolism in the urban environment. Each of these three contributions was determined by an inventory approach (Sailor and $\mathrm{Lu}, 2004$ ). 
198 prototype's hourly energy consumption profile retrieved from monthly energy use data for the building

199 sector available for the year 2000. Details of the method are described by Sailor and Lu (2004) and Heiple

200 and Sailor (2008). The parcels were then aggregated up to the grid cell scale (500-m spatial resolution) generated by a mesoscale meteorological model (Ching et al., 2008). The total quantity of heat emissions

202 from vehicles in the city is composed of emissions on freeways and emissions on other roadways. For each

203 road type we assume these heat emissions to be distributed equally across the entire length of that type of

204 roadway in the city. To determine the amount of vehicle waste heat emissions within any individual grid cell

205 we simply scale the city's total vehicle emissions on each road type by the corresponding fraction of that

206 road type contained within the grid cell of interest (Heiple and Sailor, 2008). In other words, if the city

207 contains $50 \mathrm{~km}$ of freeway lanes and the grid cell of interest contains $1 \mathrm{~km}$ of freeway, the grid cell is

208 assigned $2 \%$ of all freeway vehicle heat emissions from the city. Human metabolism was assumed to be 175

209 W during daytime and $75 \mathrm{~W}$ during nighttime (Sailor and Lu, 2004). Although all datasets were used to

210 retrieve hourly waste heat profiles the results nominally represent monthly waste heat emissions.

212 2.6. Footprint-weighted inventory approach

213 In addition to the "traditional" approaches including the energy balance closure approach (e.g. Christen 214 and Vogt, 2004) and the inventory approach (e.g. Quah and Roth, 2012), we developed a new 'footprint215 weighted inventory' approach to estimate $Q_{f}$. First, a total of 36 grid cells of AHI data were retrieved within 216 the study domain (Figure 1), and the hourly averaged flux footprint was considered for a more accurate 217 comparison with the direct flux measurement. To achieve that, we linearly downscaled the spatial resolution 218 of the AHI $(500 \mathrm{~m})$ to the $30 \mathrm{~m}$ footprint resolution, then multiplied the two matrix data sets $(200 \times 200$ cells) 219 with each other, followed by a spatial normalization by dividing by the total number of available data per 220 grid point. By summing data for each hour, we finally obtained the hourly footprint-weighted anthropogenic heat flux data, representing the $Q_{f}$ in eq. (1).

222

223

224

225

226

227

228

229

230

231

232

233

234

235 236

\section{Results and Discussion}

\subsection{Meteorological observations}

Seasonal diurnal meteorological measurements and wind roses are displayed in Figure 2. Air temperature shows a clear seasonal variation with a mean value ranging from $17.8^{\circ} \mathrm{C}$ in winter to $28.9{ }^{\circ} \mathrm{C}$ in summer; the highest temperature reaching $37.5^{\circ} \mathrm{C}$ in summer 2007 , much higher than that of the warmest month $\left(29.2^{\circ} \mathrm{C}\right.$ for August) in Houston, and the lowest temperature of approximately $-1{ }^{\circ} \mathrm{C}$ in winter $2007 / 08$, much lower than the that of the coldest month $\left(11.7^{\circ} \mathrm{C}\right.$ for January) (http://www.srh.noaa.gov/hgx/?n=climate_iah_normals_summary). Wind directions varied around the prevailing southerly flows $\left(135^{\circ}-225^{\circ}\right)$, dominant in summer $(72 \%)$ followed by spring $(64 \%)$, winter (49\%) and autumn (48\%). Particularly in autumn, NE wind directions accounted for approximately $30 \%$ during the study period. Climatologically in Houston, summers (June) are the dominant rainfall season, with the least rain falling in winters (February). However, during the study period, the highest rainfall amount, three times the climatological value, occurred in September 2008 due to hurricane Ike (Schade, 2012). 
Figure 3 displays the seasonal diurnal variation of median half-hourly SEB fluxes for all wind directions excluding \pm 30 degrees around north due to possible influences from the tower structure. The data are summarized in Table 2 for the four seasons. As expected, the median diurnal and seasonal variation of $Q^{*}$ followed the solar zenith angle variation with a peak value of $560 \mathrm{~W} \mathrm{~m}^{-2}$ in summer (JJA) and $330 \mathrm{~W} \mathrm{~m}^{-2}$ in winter (DJF). $Q^{*}$ typically changed sign an hour later and earlier in the morning and the evening, respectively, than measured incoming radiation. The peak of median $\mathrm{H}$ was typically delayed by one half to one hour, and it dominated heat fluxes at $44 \%$ of $Q^{*}$ during daytime $\left(Q^{*}>0\right)$. H was generally proportional to $Q^{*}$ variation, a characteristic in subtropical climates (Roth, 2007). The peak value of median $\mathrm{H}$ was 201 $\mathrm{W} \mathrm{m} \mathrm{m}^{-2}$ in summer and $120 \mathrm{~W} \mathrm{~m}^{-2}$ in winter. In addition, $\mathrm{H}$ remained positive for two and a half hours to one hour after $Q^{*}$ had changed sign to negative, depending on the seasonal surface temperature, due to lagged surface heating by previously stored heat. However, the heat stored in the urban impervious fabric during daytime was not dominantly converted into sensible heat flux during nighttime, meaning median $\mathrm{H}$ remained slightly negative ( -9 to $-1 \mathrm{~W} \mathrm{~m}^{-2}$ ) at night throughout the years.

The diurnal median values of LE varied along with $\mathrm{H}$, but peak daytime values occurred within a wider range between 11:00 and 14:00 LST. Latent heat fluxes were virtually always positive except for small variations around zero during nighttime, with peak values of $123 \mathrm{~W} \mathrm{~m}^{-2}$ (summer) and $38 \mathrm{~W} \mathrm{~m}^{-2}$ (winter). While this seasonal change is expected from reductions in LAI and temperature, the drop was larger than that of $Q^{*}(67 \%$ vs. $38 \%)$. This may appear larger than expected since in urban areas latent heat fluxes are typically driven not only by the amount of transpiration of the onsite vegetation but also anthropogenic evapotranspiration supply in the form of irrigation. However, the latter is essentially absent around our site with the exception of a few, more affluent homeowners watering small lawns, and two larger lawn areas belonging to nearby schools. Both represent less than $10 \%$ of the area within the $90 \%$ footprint limits. Nevertheless, although the amount of photosynthetically active foliage is much lower in winter (>90\% of leaves in this area are deciduous; Park et al., 2011), the mild winter climate alongside a small live oak population, lawns and evergreen bushes appears to provide for significant winter time latent heat flux.

Results from a 1-yr study in subtropical Phoenix, AZ (Chow et al, 2014), and a shorter study in São Paulo, Brazil (Ferreira, 2013), can be compared with our study results. In São Paulo, daily mean values of H and LE were approximately half as high in summer, likely driven by a daily averaged $Q^{*}$ value also only half that of Houston, although the city is located at a lower latitude $\left(23^{\circ} \mathrm{S}\right)$ and its impervious area fraction was similar to ours. In Phoenix $\left(33^{\circ} \mathrm{N}\right)$, daily averaged $Q^{*}$ and $\mathrm{H}$ were closer to our mean values in summer, and approximately $35 \%$ lower in winter, while LE values were $50 \%$ lower in summer and winter, which is reasonable considering the much lower vegetation fraction in Phoenix ( 15\%). In response to the high vegetation fraction at our study site ( $45 \%$ of coverage), the LE is significant and its magnitude varies as a function of moisture availability and on the amount of vegetation in the footprint. This affects the residual flux.

The general diurnal variation of Res (Figure 4) shows that it steeply rises in the early morning along with the $Q^{*}$ variation, then reaches a maximum before noon $\left(221 \mathrm{~W} \mathrm{~m}^{-2}\right.$ in summer and $140 \mathrm{~W} \mathrm{~m}^{-2}$ in winter), and decreases continually afterwards to negative values before $~ 16: 00 \mathrm{LST}$, reaching a minimum 
277 hourly median Res ranged from -100 to $241 \mathrm{~W} \mathrm{~m}^{-2}$. Compared with other long-term (>1yr) urban

278 measurement sites, such as Phoenix, AZ (-4 to $83 \mathrm{~W} \mathrm{~m}^{-2}$ ), Helsinki, Finland (-53 to $69 \mathrm{~W} \mathrm{~m}^{-2}$; Nordbo et al.,

279 2012) and Lodz, Poland (-100 to $180 \mathrm{~W} \mathrm{~m}^{-2}$; Offerle et al., 2005), the Houston Res showed a higher

280 maximum, likely due to higher $Q^{*}$. For similar reasons, daytime Res showed a steeper increase and reached

281 an earlier peak than $\mathrm{H}$, with its overall magnitude higher than that of $\mathrm{H}$ in all seasons except spring. This

282 characteristic has been observed at other suburban sites (Ferreira et al., 2013; Coutts et al., 2007; Grimmond

283 and Oke, 1995).

284

285

\subsection{Energy partitioning}

In Figure 5 we show the diurnal variation of the ratios $\mathrm{H} / Q^{*}, \mathrm{LE} / Q^{*}, \operatorname{Res} / Q^{*}$ and $\beta=\mathrm{H} / \mathrm{LE}$. The

287

288

289

290

291

292

293

294

295

296

297

298

299

300

301

302

303

304

305

306

307

308

309

310

311

312

313

314

315

316 upward spikes around 16:00 - 17:00 LST in both $\mathrm{H} / Q^{*}$ and $\mathrm{LE} / Q^{*}$ were in part due to a rapid decline of net radiation as compared to both $\mathrm{H}$ and LE (Figure 4). $\mathrm{H} / Q^{*}$ exceeded 100\% around 16:00 LST in winter possibly as a result of relatively higher contributions from $Q_{f}$ in the form of space heating and car traffic. The LE fraction of $Q^{*}$ was on average zero during nighttime and positive in daytime throughout the study period. After sunrise it increased until it contributed approximately $50 \%$ of net radiation in late afternoon, then changed the sign to negative after sunset, and gradually restored to zero thereafter.

The $\operatorname{Res} / Q *$ ratio decreased from a maximum value exceeding $100 \%$ after sunset to approximately zero around mid-afternoon (15:30 LST), when local temperatures maximize. It remained very high for most of the night hours after its peak contribution around sunset, meaning radiative heat loss is dominantly supplied by the heat stored in the urban canopy.

Seasonal differences are obvious in timing but relatively small regarding the fractional distribution of the SEB fluxes. Except during the winter, sensible heat fluxes constitute a minor nighttime flux contribution as compared to radiative heat losses. In winter, $\mathrm{H}$ may contribute up to $36 \%$ of the heat loss during the early morning hours, suggesting that the residual at that time is driven by heat storage in the urban canopy, delaying the rise of $\mathrm{H}$ as compared to in natural environments. Peak $\beta$ was observed in the early afternoon time as plant transpiration begins to decline. During daytime, the highest mean value of $\beta$ was $\sim 3.6$ in winter due to lower transpiration rates, and the lowest value was $\sim 1.6$ in summer due to higher evapotranspiration and amount of precipitation.

The diurnal and seasonal analysis of normalized SEB in Figure 5 shows a mirror hysteresis pattern of $\mathrm{H} / Q^{*}$ and $R e s / Q^{*}$ that has also been observed in other cities (e.g. Roth, 2007; Ferreira et al., 2013; Chow et al., 2014). This pattern is reflected in urban atmospheric boundary layer dynamics, such that lower $\mathrm{H}$ is observed after sunrise but high daytime sensible heat fluxes induce convection that is maintained into the evening, at times several hours past sunset. As a result, urban anthropogenic pollutant mixing ratios strongly peak during the morning rush hours, but no such peak is observable during the afternoon rush hours (Park et al., 2010).

\subsection{Directionality of measured fluxes}

We investigated the seasonal aspects of fluxes of $\mathrm{H}$ and LE by wind direction (Figure 6a and b): the NW and $\mathrm{W}$ directions showed 66\% - 79\% and 9\% - 75\% higher median values than the other directions,

(C) 2015. This manuscript version is made available under the CC-BY-NC-ND 4.0 license http://creativecommons.org/licenses/by-nc-nd/4.0/ 
317 total ensemble mean average value and was even lower for the $\mathrm{W}$ directions, which include a park and a

318 cemetery. There were no obvious differences in the footprint areas between seasons (Figure S1 in

319 Supporting Information) and no obvious land use differences other than the green areas. Higher fluxes,

320 including $\mathrm{CO}_{2}$ flux (Figure 6c), from NW directions are nevertheless likely caused by anthropogenic

321 industrial activities. Several small and mid-size oil \& gas supply manufacturers are located within a 500-m

322 radius of the tower (Figure 1). A large metal surface coating company in the immediate NW operates large

323 ovens fueled by gas burners on a regular basis, venting through the roof exhaust hoods only $100 \mathrm{~m}$ from the

324 tower, thus explaining all or most of the observed higher fluxes from that direction. Its source appears either

325 missing from the AHI or is blended into a larger area since the company has another location outside the

326 study area.

327 In the E direction from the tower, only LE showed relatively higher fluxes. Judging from the slightly

328 lower $\mathrm{CO}_{2}$ flux, these higher fluxes are likely not related to an industrial source process, but rather to a

329 slightly larger amount of tree foliage on mature urban trees near the tower's maximum footprint impact

330 areas. Unlike for the W and NW directions from the tower, few distinctive anthropogenic heat sources were

331 identified, but no industrial heat sources were located within $1 \mathrm{~km}$ east from the tower.

332

333

\subsection{Estimate of annual emission of anthropogenic heat}

In our study domain, the total ensemble mean values of AHI were $\sim 34 \mathrm{~W} \mathrm{~m}^{-2}$ in both summer and winter, which are approximately four times higher than those for the entire city of Houston $\left(\sim 9 \mathrm{~W} \mathrm{~m}^{-2}\right)$, but only a third of the values for downtown Houston (101 $\mathrm{W} \mathrm{m}^{-2}$ in summer and $104 \mathrm{~W} \mathrm{~m}^{-2}$ in winter). This indicates that the study site represents a relatively higher energy consumption area, possibly due to its rather old, energy inefficient residential and commercial housing structures cooled by old, inefficient air conditioners. Per capita, however, our domain emitted approximately $48 \mathrm{~W} \mathrm{~m}^{-2}$, which is approximately $50 \%$ and $30 \%$ lower than values for downtown $\left(\sim 102 \mathrm{~W} \mathrm{~m}^{-2}\right.$ per capita) and of the whole city $\left(\sim 68 \mathrm{~W} \mathrm{~m}^{-2}\right.$ per capita), respectively, during a typical summer month (August). This lower value of per-capita emission implies that the local waste heat sources are not likely dominated by local residents.

Since the AHI data were only available for summer and winter, we estimated annual anthropogenic heat release under the assumption that the vehicles are the main heat emission sources in the study domain. Based on Harris county traffic count data (http://www.eng.hctx.net/traffic/hc_counts.PDF), the traffic counts in spring and autumn were approximately $85 \%$ of those in summer, while there was no difference between summer and winter during the study period. Thus, we assigned $29 \mathrm{~W} \mathrm{~m}^{-2}$ to the spring and autumn AHI heat flux. Averaging the four seasonal AHI heat fluxes then resulted in $32 \mathrm{~W} \mathrm{~m}^{-2}$ annual-basis $Q_{f}$ fluxes.

This value can be compared to the energy closure approach, calculated when the net storage heat flux $(\Delta Q s)$ in eq. (1) becomes zero in the long-term (> 1yr) over all footprint areas, and Res becomes representative of $Q_{f}$. The calculated annually averaged Res-driven $Q_{f}$ was $27 \pm 1 \mathrm{~W} \mathrm{~m}^{-2}\left(25 \pm 1 \mathrm{~W} \mathrm{~m}^{-2}\right.$ when excluding NW directions) based on a total of 13 12-month periods throughout the study period, approximately $15 \%$ lower than the AHI-based annual $Q_{f}$.

In a further extension, applying the 'footprint-weighted inventory' approach (Section 2.6) resulted in averaged $Q_{f}$ values of $24 \mathrm{~W} \mathrm{~m}^{-2}$ (summer) and $22 \mathrm{~W} \mathrm{~m}^{-2}$ (winter). These values are virtually identical to the 
356 Res-driven $Q_{f}$, and were only slightly lowered when considering the seasonal variation of traffic volume (20$\left.35722 \mathrm{~W} \mathrm{~m}^{-2}\right)$.

358 These $Q_{f}$ values are similar to anthropogenic annual mean waste heat emissions calculated in previous studies in a (sub)tropical areas: $11-85 \mathrm{~W} \mathrm{~m}^{-2}$ in Singapore (Quah and Roth, 2012) and $5-25 \mathrm{~W} \mathrm{~m}^{-2}$ in São Paulo, Brazil (Ferreira et al., 2011), which were estimated by inventory approaches. Waste heat emissions in non-subtropical areas are also comparable: $5-10 \mathrm{~W} \mathrm{~m}^{-2}$ in Swindon, UK (Ward et al., 2013), $11 \mathrm{~W} \mathrm{~m}^{-2}$ in London (Iamarino et al., 2012), and $35 \mathrm{~W} \mathrm{~m}^{-2}$ in Reykjavik, Iceland (Steinecke, 1999) derived from energy consumption and population statistics; and $13 \mathrm{~W} \mathrm{~m}^{-2}$ and $20 \mathrm{~W} \mathrm{~m}^{-2}$ in Helsinki, Finland (Nordbo et al., 2012), and in Basel, Switzerland (Christen and Vogt, 2004), respectively, under the assumption that $\Delta Q s$ averages to zero over long time periods. Note, that the observed lack of seasonality of $Q_{f}$ was also reported for Sao Paulo, Brazil (Ferreira et al., 2011), and Los Angeles, CA (Sailor and Lu, 2004), both cities with similarly low annual temperature seasonality, and stands in contrast to cities at higher latitudes, e.g., Lodz, Poland (Offerle et al., 2005) and Swindon, UK (Ward et al., 2013), which emit much higher waste heat in winter.

Lastly, we estimated $\Delta Q s$ by directly solving eq. (2) using the measured fluxes and the footprintweighted $Q_{f}$. The seasonally averaged diurnal variations of $\Delta Q s, Q_{f}$ and $R e s$ are shown in Figure 7. The relatively late occurring peak in $\Delta Q s$ has been reported in the other subtropical studies including Mexico City and Mexicali as reviewed by Roth (2007), and São Paulo, Brazil (Ferreira et al., 2013), possibly a feature of subtropical urban SEB. The average $\Delta Q s$ was $128 \mathrm{~W} \mathrm{~m}^{-2}$ (daytime) and $-41 \mathrm{~W} \mathrm{~m}^{-2}$ (nighttime) in summer, and $105 \mathrm{~W} \mathrm{~m}^{-2}$ (daytime) and $-16 \mathrm{~W} \mathrm{~m}^{-2}$ (nighttime) in winter. Considering the lack of difference of $Q_{f}$ between summer and winter $(<8 \%)$, the higher $\Delta Q s$ in summer is due to higher $Q^{*}$ values.

\section{Summary and Conclusion}

We investigated the surface energy balance in a humid subtropical urban area. The measurements of $Q^{*}, \mathrm{H}$ and $\mathrm{LE}$ from a tall flux tower using an $\mathrm{EC}$ system for two years showed expected diurnal and seasonal variations, highest in summer, lowest in winter. The partitioning of $Q^{*}$ into $\mathrm{H}$ and LE was $42 \%$ (IQR: $27 \%$ to $65 \%$ ) and $22 \%$ (IQR: $11 \%$ to $42 \%$ ) during daytime, respectively. The mean $\beta$ ranged from 1.2 in summer to 2.1 in winter, and showed the expected seasonal effect from LE as driven by a higher amount of evapotranspiration in summer, and a lower amount of foliage in winter.

Temporal aspects of $\mathrm{H}, \mathrm{LE}$ and $\mathrm{CO}_{2}$ flux by wind direction revealed potential anthropogenic heat sources contributing to $\mathrm{H}$ within a short radius from the tower, identified as small and medium metal processing industries in NW and W directions; higher LE fluxes from E and SE directions were attributed to the local tree canopy. Both of these sources were corroborated by the measured $\mathrm{CO}_{2}$ fluxes since $\mathrm{NW}$ wind directions carried higher heat and $\mathrm{CO}_{2}$ fluxes from an industrial heating process (burner) and SE wind directions carried higher water vapor and lower $\mathrm{CO}_{2}$ fluxes as a result of photosynthesis in the locally denser tree canopy.

Heat storage in the urban fabric was calculated by the residual method. It contributed more than a 50\% of median $Q^{*}$ both in summer and winter, a somewhat large amount considering the average land cover statistics in the study domain. This may be due to the mismatch of footprint areas between radiation and flux (Figure 1), inducing an energy balance closure problem (Offerle et al., 2005). Within the radiative footprint area, a significantly lower vegetation fraction and dominant impervious area likely result not only in a higher 
396 Bowen ratio, but may have also lead to higher $Q^{*}$ due to a lower albedo, and a resulting overestimate of the

397 storage flux within the larger H+LE flux domain.

398 The local $Q_{f}$ was estimated in different ways including (1) the inventory approach, (2) the energy

399 balance closure approach, and (3) the newly introduced 'footprint-weighted inventory' approach. The values

400 calculated by the two inventory based approaches $(1,3)$ showed a range of annual $Q_{f}$ from 20 to $30 \mathrm{~W} \mathrm{~m}^{-2}$,

401 closely corresponding to the Res-driven $Q_{f}$. Considering possible discrepancies between $Q_{f}$ values calculated

402 by methods 1 and 2, the 'footprint-weighted inventory' method may represent an improvement in areas of

403 heterogeneous surface coverage, but, for validation purposes, should be applied on a higher spatial

404 resolution gridded dataset generated by building-scale energy modeling imbedded in urban canopy models.

405 Further investigations into the residual of the energy balance are intended to better characterize the UHI

406 estimate. Use of a mesoscale numerical model coupled with an urban climate module may be necessary to

407 quantify the effect of anthropogenic heat in regional-scale atmospheric environments.

408

409

Acknowledgements

410 We are indebted to the Houston Yellow Cab Co. allowing us to carry out this project on their property

411 and radio communications tower. We especially thank employees William Hernandez and Pernman

412 Vondenstein for their tireless support of our research efforts. We also thank graduate student Ian Boedeker

413 for his indispensable contributions to the project via maintaining tower installations and processing raw data

414 in EdiRe, as well as two anonymous reviewers whose comments improved the manuscript. This project was

415 funded via two grants from the Texas Air Research Center (TARC) and a startup grant to G. Schade by

416 Texas A\&M University. C. Park acknowledges the financial support of the "2012 Post-Doc Development

417 Program" of Pusan National University in South Korea. The graphs in Figure 2 and Figure 6 were created

418 using Openair R (http://www.openair-project.org/).

References

423

424

425

426

427

428

429

430

431

432

433

434

435

436

437

438

439

440

Arnfield, A.J., 2003. Two decades of urban climate research: A review of turbulence, exchanges of energy and water, and the urban heat island. Int J Climatol 23, 1-26.

Ching, J., Brown, M., Burian, S., Chen, F., Cionco, R., Hanna, A., Hultgren, T., McPherson, T., Sailor, D., Taha, H., Williams, D., 2009. National Urban Database and Access Portal Tool. B Am Meteorol Soc 90, $1157-+$.

Chow, W.T.L., Volo, T.J., Vivoni, E.R., Jenerette, G.D., Ruddell, B.L., 2014. Seasonal dynamics of a suburban energy balance in Phoenix, Arizona. Int J Climatol 34, 3863-3880.

Christen, A., Vogt, R., 2004. Energy and radiation balance of a central European city. Int J Climatol 24, 1395-1421.

Coutts, A.M., Beringer, J., Tapper, N.J., 2007. Impact of increasing urban density on local climate: Spatial and temporal variations in the surface energy balance in Melbourne, Australia. J Appl Meteorol Clim 46, 477-493.

441 Ferreira, M.J., de Oliveira, A.P., Soares, J., 2011. Anthropogenic heat in the city of São Paulo, Brazil. 
442

443

444

445

446

447

448

449

450

451

452

453

454

455

456

457

458

459

460

461

462

463

464

465

466

467

468

469

470

471

472

473

474

475

476

477

478

479

480

481

482

483

484

485

486

487

488

489

490

491

492

493

494

495

496

497

498

499

500

501

Theoretical and Applied Climatology 104, 43-56.

Ferreira, M. J., A. P. Oliveira, and J. Soares, 2013. Diurnal variation in stored energy flux in São Paulo city, Brazil, Urban Climate, 5, 36-51.

Foken, T., Wichura, B., 1996. Tools for quality assessment of surface-based flux measurements. Agricultural and Forest Meteorology 78, 83-105.

Foken, T., 2008. The energy balance closure problem: An overview. Ecol Appl 18, 1351-1367.

Grimmond, C.S.B., Cleugh, H.A., Oke, T.R., 1991. An Objective Urban Heat-Storage Model and Its Comparison with Other Schemes. Atmos Environ B-Urb 25, 311-326.

Grimmond, C.S.B., Oke, T.R., 1995. Comparison of Heat Fluxes from Summertime Observations in the Suburbs of 4 North-American Cities. J Appl Meteorol 34, 873-889.

Grimmond, C.S.B., Oke, T.R., 1999. Heat storage in urban areas: Local-scale observations and evaluation of a simple model. J Appl Meteorol 38, 922-940.

Heiple, S., Sailor, D.J., 2008. Using building energy simulation and geospatial modeling techniques to determine high resolution building sector energy consumption profiles. Energ Buildings 40, 1426-1436.

Hsieh, K.J., Lien, F.S., Yee, E., 2007. Numerical modeling of passive scalar dispersion in an urban canopy layer. J Wind Eng Ind Aerod 95, 1611-1636.

Iamarino, M., Beevers, S., Grimmond, C.S.B., 2012. High-resolution (space, time) anthropogenic heat emissions: London 1970-2025. Int J Climatol 32, 1754-1767.

Ibrom, A., Dellwik, E., Flyvbjerg, H., Jensen, N.O., Pilegaard, K., 2007. Strong low-pass filtering effects on water vapour flux measurements with closed-path eddy correlation systems. Agricultural and Forest Meteorology 147, 140-156.

Kikegawa, Y., Genchi, Y., Kondo, H., Hanaki, K., 2006. Impacts of city-block-scale countermeasures against urban heat-island phenomena upon a building's energy-consumption for air-conditioning. Appl Energ 83, 649-668.

Kljun, N., Calanca, P., Rotach, M.W., Schmid, H.P., 2004. A simple parameterisation for flux footprint predictions. Boundary-Layer Meteorology 112, 503-523.

Kormann, R., Meixner, F.X., 2001. An analytical footprint model for non-neutral stratification. BoundaryLayer Meteorology 99, 207-224.

Kotthaus, S., and Grimmond, C.S.B., 2013, Energy exchange in a dense urban environment - Part I: Temporal variability of long-term observations in central London, Urban Climate, 10(2): 261-280.

Mauder, M., Oncley, S.P., Vogt, R., Weidinger, T., Ribeiro, L., Bernhofer, C., Foken, T., Kohsiek, W., De Bruin, H.A.R., Liu, H., 2007. The energy balance experiment EBEX-2000. Part II: Intercomparison of eddycovariance sensors and post-field data processing methods. Boundary-Layer Meteorology 123, 29-54.

Moriwaki, R., Kanda, M., 2004. Seasonal and diurnal fluxes of radiation, heat, water vapor, and carbon dioxide over a suburban area. J Appl Meteorol 43, 1700-1710.

Nordbo, A., Jarvi, L., Vesala, T., 2012. Revised eddy covariance flux calculation methodologies - effect on urban energy balance. Tellus Series B-Chemical and Physical Meteorology 64.

Offerle, B., Grimmond, C.S.B., Fortuniak, K., 2005. Heat storage and anthropogenic heat flux in relation to the energy balance of a central European city centre. Int J Climatol 25, 1405-1419.

(C) 2015. This manuscript version is made available under the CC-BY-NC-ND 4.0 license http://creativecommons.org/licenses/by-nc-nd/4.0/ 
Park, C., Schade, G.W., Boedeker, I., 2010. Flux measurements of volatile organic compounds by the relaxed eddy accumulation method combined with a GC-FID system in urban Houston, Texas. Atmospheric

Park, C., Schade, G.W., Boedeker, I., 2010. Flux measurements of volatile organic compounds by the Environment 44, 2605-2614.

Park, C., Schade, G.W., Boedeker, I., 2011. Characteristics of the flux of isoprene and its oxidation products in an urban area. J Geophys Res-Atmos 116.

Quah, A.K.L., Roth, M., 2012. Diurnal and weekly variation of anthropogenic heat emissions in a tropical city, Singapore. Atmospheric Environment 46, 92-103.

Roberts, S.M., Oke, T.R., Grimmond, C.S.B., Voogt, J.A., 2006. Comparison of four methods to estimate urban heat storage. J Appl Meteorol Clim 45, 1766-1781.

Rotach, M.W., Vogt, R., Bernhofer, C., Batchvarova, E., Christen, A., Clappier, A., Feddersen, B., Gryning, S.E., Martucci, G., Mayer, H., Mitev, V., Oke, T.R., Parlow, E., Richner, H., Roth, M., Roulet, Y.A., Ruffieux, D., Salmond, J.A., Schatzmann, M., Voogt, J.A., 2005. BUBBLE - An urban boundary layer meteorology project. Theoretical and Applied Climatology 81, 231-261.

Roth, M., 2007. Review of urban climate research in (sub)tropical regions. Int J Climatol 27, 1859-1873.

Sailor, D.J., 2011. A review of methods for estimating anthropogenic heat and moisture emissions in the urban environment. Int J Climatol 31, 189-199.

Sailor, D.J., Lu, L., 2004. A top-down methodology for developing diurnal and seasonal anthropogenic heating profiles for urban areas. Atmospheric Environment 38, 2737-2748.

Schade, G.W., 2009. Relating urban turbulence and trace gas flux measurements from a tall tower to surface characteristics and anthropogenic activities, a report to the Texas Air Research Center (TARC).

Schade, G.W., 2012. Meteorological characteristics of Hurricane Ike during its passage over Houston, Texas, in: Hurricane Research, edited by Kieran Hickey, ISBN 980-953-307-559-9.

Schmid, H.P., Cleugh, H.A., Grimmond, C.S.B., Oke, T.R., 1991. Spatial Variability of Energy Fluxes in Suburban Terrain. Boundary-Layer Meteorology 54, 249-276.

Steinecke, K., 1999. Urban climatological studies in the Reykjavik subarctic environment, Iceland. Atmospheric Environment 33, 4157-4162.

Vesala, T., Jarvi, L., Launiainen, S., Sogachev, A., Rannik, U., Mammarella, I., Siivola, E., Keronen, P., Rinne, J., Riikonen, A., Nikinmaa, E., 2008. Surface-atmosphere interactions over complex urban terrain in Helsinki, Finland. Tellus Series B-Chemical and Physical Meteorology 60, 188-199.

Ward, H.C., Evans, J.G., Grimmond, C.S.B., 2013. Multi-season eddy covariance observations of energy, water and carbon fluxes over a suburban area in Swindon, UK. Atmospheric Chemistry and Physics 13, 4645-4666.

Werner, N., 2013, Anthropogenic and biogenic carbon dioxide fluxes from typical land uses in Houston, Texas, MS thesis, Texas A\&M University.

558 
Table 1. Subset of installed (micro-) meteorological sensors on the Yellow Cab tower

\begin{tabular}{|c|c|c|c|}
\hline Parameter & Sensor (model) & Elevation & Unit \\
\hline Wind speed & Cup anemometer (034B $\left.{ }^{1}\right)$ & $60 \mathrm{~m}$ & $\mathrm{~m} \mathrm{~s}^{-1}$ \\
\hline Wind direction & Wind vane $\left(034 \mathrm{~B}^{1}\right)$ & $60 \mathrm{~m}$ & degrees \\
\hline Pressure & Silicon capacitance $(\text { Setra } 278)^{2}$ & $2 \mathrm{~m}$ & $\mathrm{kPa} / \mathrm{mbar}$ \\
\hline Precipitation & TE525-L 6" (tipping bucket) ${ }^{3}$ & $12 \mathrm{~m}$ & $\mathrm{~mm}$ \\
\hline Incident solar radiation & Pyranometer (300-1100 nm) ${ }^{4}$ & $60 \mathrm{~m}$ & $\mathrm{~W} \mathrm{~m}^{-2}$ \\
\hline Net radiation & Thermopile (NR-LITE-L) ${ }^{2}$ & $60 \mathrm{~m}$ & $\mathrm{~W} \mathrm{~m} \mathrm{~m}^{-2}$ \\
\hline 3-D wind speed + dir. $(2008)$ & Sonic anemometer (CSAT3) ${ }^{2}$ & $60 \mathrm{~m}$ & $\mathrm{~m} \mathrm{~s}^{-1} / \mathrm{deg}$ \\
\hline \multicolumn{4}{|l|}{${ }^{1}$ MetOne Instruments } \\
\hline \multicolumn{4}{|l|}{${ }^{2}$ Campbell Scientific, Inc. } \\
\hline \multicolumn{4}{|c|}{${ }^{3}$ Texas Instruments via Campbell Scientific, Inc. } \\
\hline \multicolumn{4}{|c|}{${ }^{4}$ Apogee } \\
\hline
\end{tabular}

Table 2. Average seasonal energy balance fluxes for $\mathrm{u}^{*} \geq 0.2 \mathrm{~m} \mathrm{~s}^{-1}$ (Unit: $\mathrm{W} \mathrm{m}^{-2}$; $5 \%$ trimmed means calculated from the half-hourly data).

\begin{tabular}{|c|c|c|c|c|}
\hline & Spring & Summer & Autumn & Winter \\
\hline \multicolumn{5}{|c|}{24 hours } \\
\hline$Q^{*}$ & 104 & 121 & 91 & 44 \\
\hline $\mathrm{H}$ & 59 & 64 & 52 & 36 \\
\hline LE & 30 & 54 & 40 & 5 \\
\hline Res & 23 & 23 & 29 & 2 \\
\hline $\mathrm{H} / Q^{*}$ & 0.28 & 0.28 & 0.26 & 0.31 \\
\hline $\mathrm{LE} / Q^{*}$ & 0.12 & 0.16 & 0.07 & 0.03 \\
\hline $\operatorname{Res} / Q^{*}$ & 0.6 & 0.56 & 0.67 & 0.66 \\
\hline$\beta$ & 2.2 & 1.32 & 1.47 & 2.84 \\
\hline $\mathrm{N}$ & 8168 & 8211 & 5984 & 6821 \\
\hline \multicolumn{5}{|c|}{ Daytime $\left(Q^{*}>0\right)$} \\
\hline$Q^{*}$ & 263 & 283 & 258 & 178 \\
\hline $\mathrm{H}$ & 117 & 115 & 101 & 89 \\
\hline LE & 57 & 88 & 67 & 31 \\
\hline Res & 85 & 85 & 100 & 65 \\
\hline $\mathrm{H} / Q^{*}$ & 0.49 & 0.43 & 0.4 & 0.57 \\
\hline $\mathrm{LE} / Q^{*}$ & 0.27 & 0.38 & 0.31 & 0.24 \\
\hline $\operatorname{Res} / Q^{*}$ & 0.24 & 0.19 & 0.27 & 0.16 \\
\hline$\beta$ & 2.12 & 1.36 & 1.57 & 3.06 \\
\hline $\mathrm{N}$ & 4221 & 4461 & 2936 & 2882 \\
\hline \multicolumn{5}{|c|}{ Nighttime $\left(Q^{*} \leq 0\right)$} \\
\hline$Q^{*}$ & -37 & -43 & -47 & -35 \\
\hline $\mathrm{H}$ & -1 & -2 & -4 & -2 \\
\hline LE & 3 & 8 & 10 & 4 \\
\hline Res & -40 & -53 & -52 & -42 \\
\hline $\mathrm{H} / Q^{*}$ & -0.05 & 0.04 & 0.04 & 0.03 \\
\hline $\mathrm{LE} / Q^{*}$ & -0.11 & -0.22 & -0.34 & -0.19 \\
\hline $\operatorname{Res} / Q^{*}$ & 1.17 & 1.19 & 1.32 & 1.22 \\
\hline$\beta$ & 0.36 & -0.05 & -0.29 & 0.22 \\
\hline $\mathrm{N}$ & 3947 & 3750 & 3048 & 3939 \\
\hline
\end{tabular}




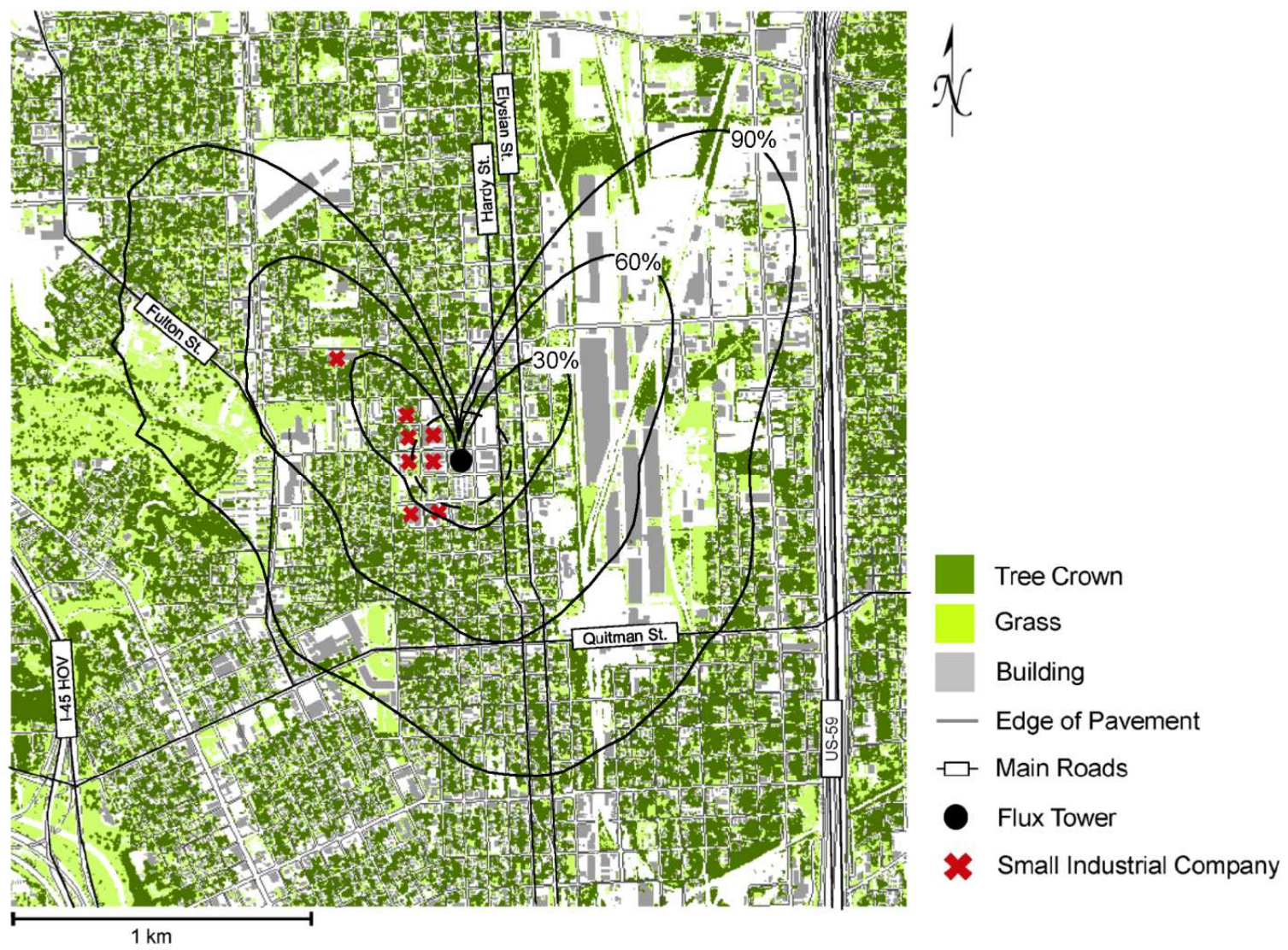

569

570

571

572

573

574

575

576

577

578

579

580

581
Figure 1. Distribution of land cover within the study domain $(3 \mathrm{~km} \times 3 \mathrm{~km})$, overlaid with the average autumn footprint function (thick black contour lines represent the probability of flux coming from within the area). The $90 \%$-level of the radiative footprint area is indicated by a dashed line circle. The footprint functions for the other seasons are in Figure S1 in the Supporting Information. 

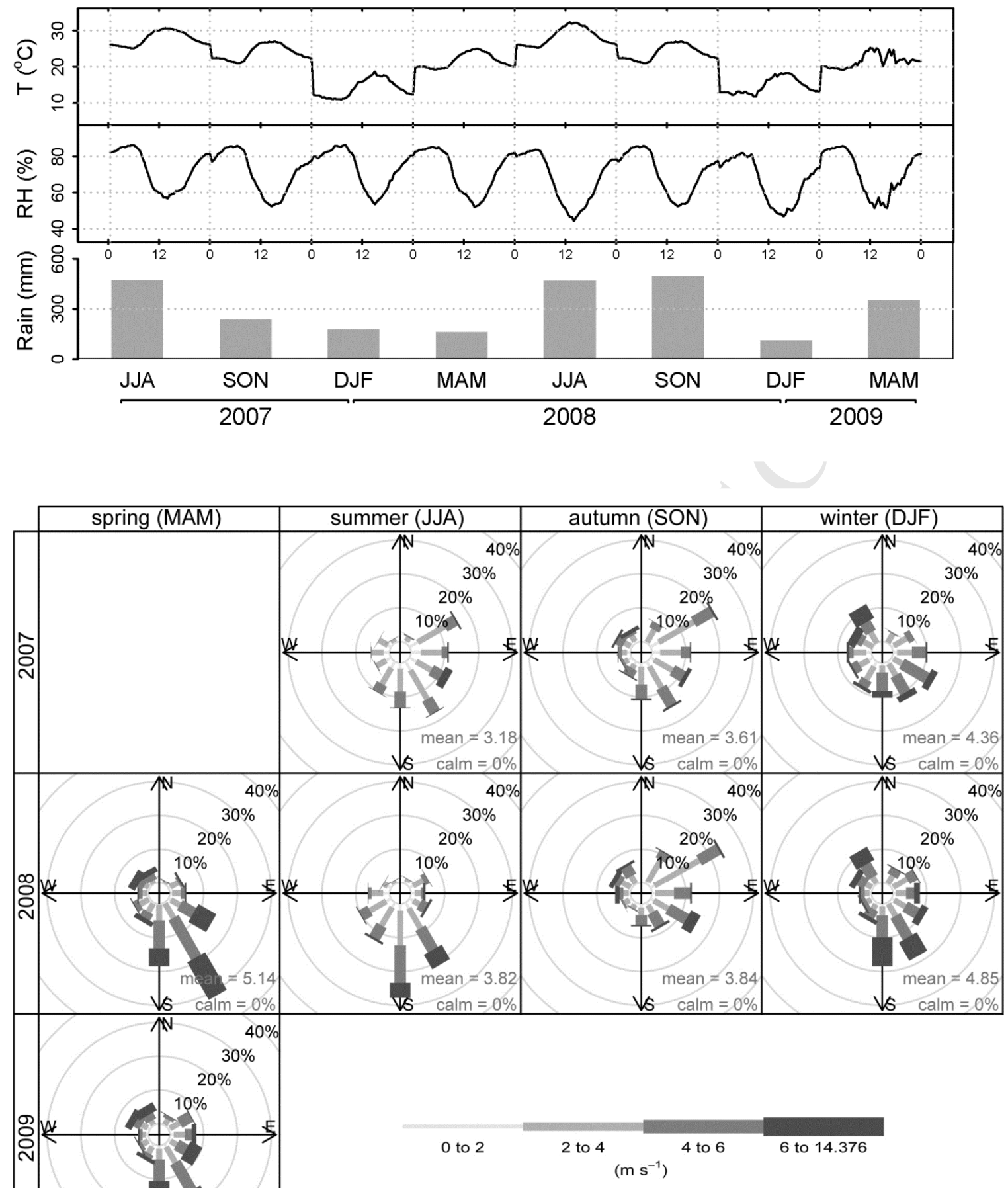

Frequency of counts by wind direction (\%) 

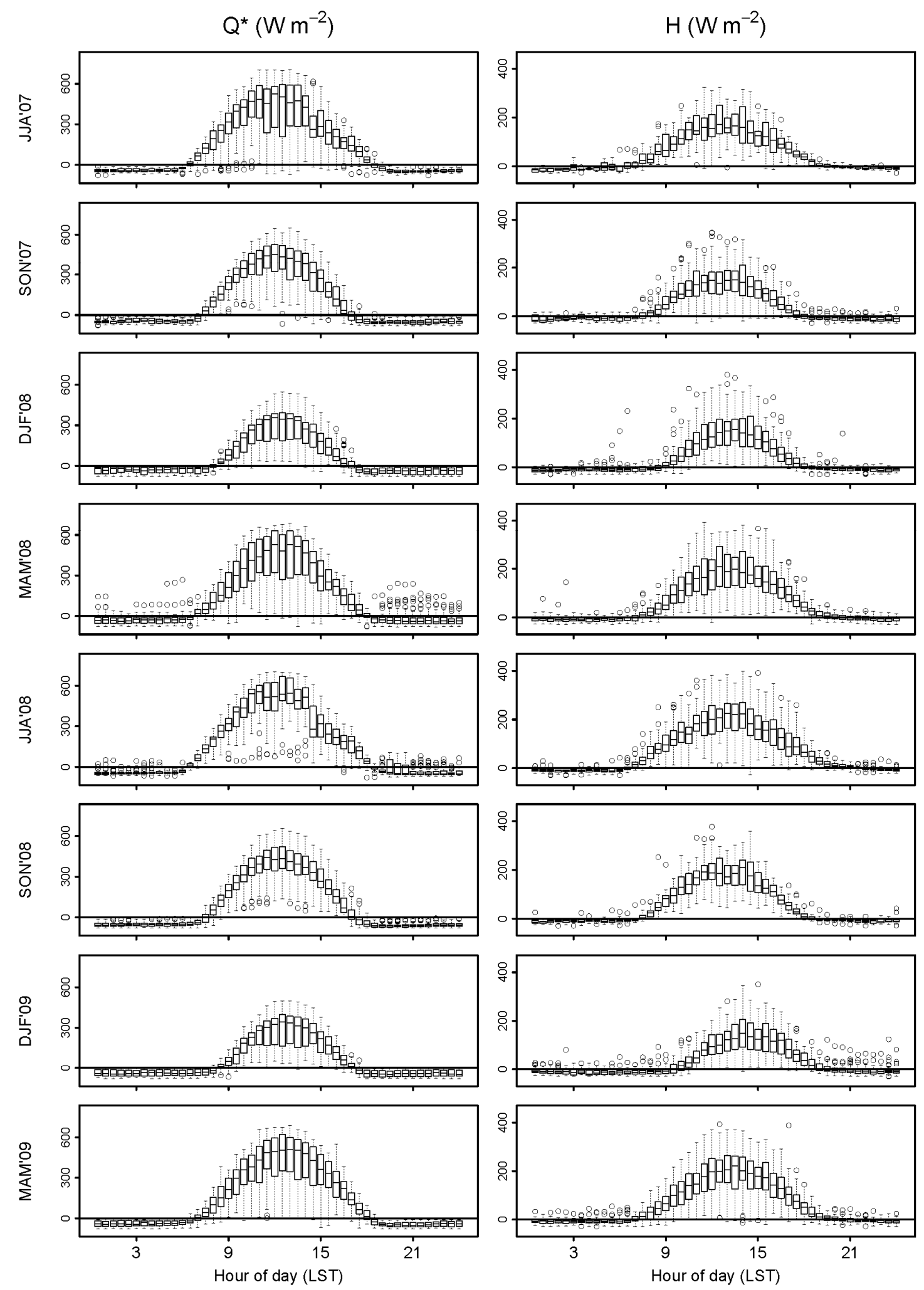

(a)

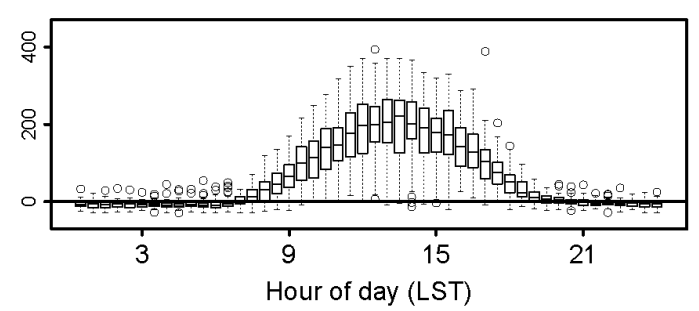

(b)

599

600 

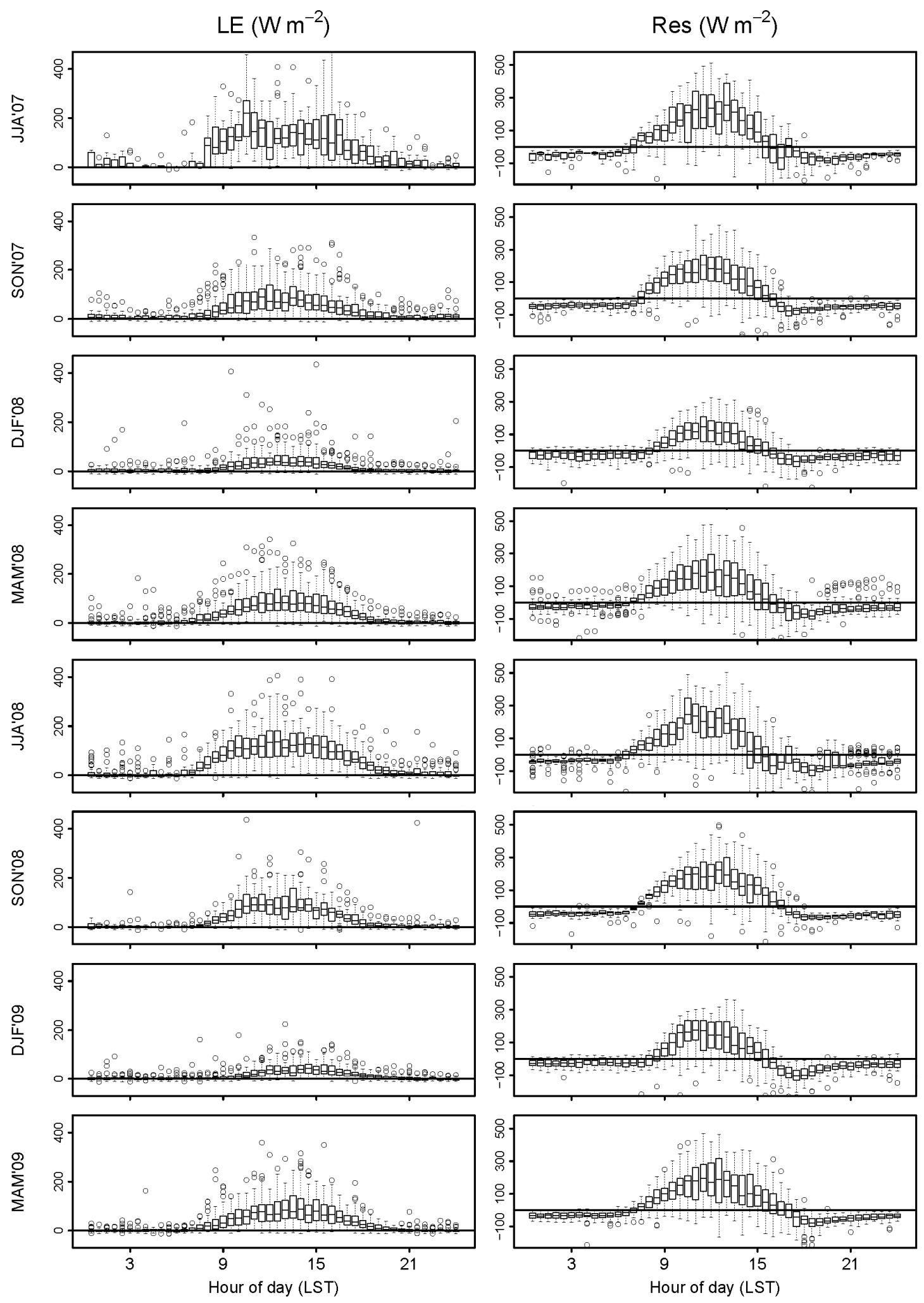

(c)

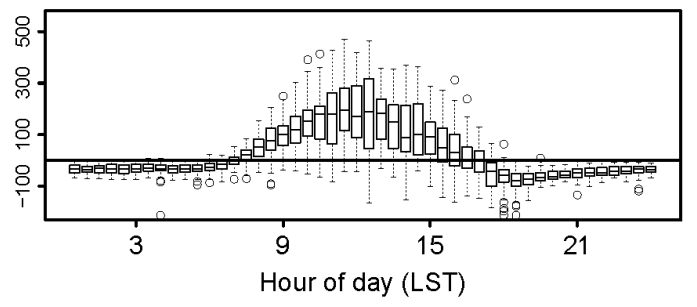

601

602

603

Figure 3. Boxplots of seasonal diurnal variation of median energy fluxes of (a) $Q^{*}$, (b) $\mathrm{H}$, (c) LE and (d) Res during the study period.

605

606

607 

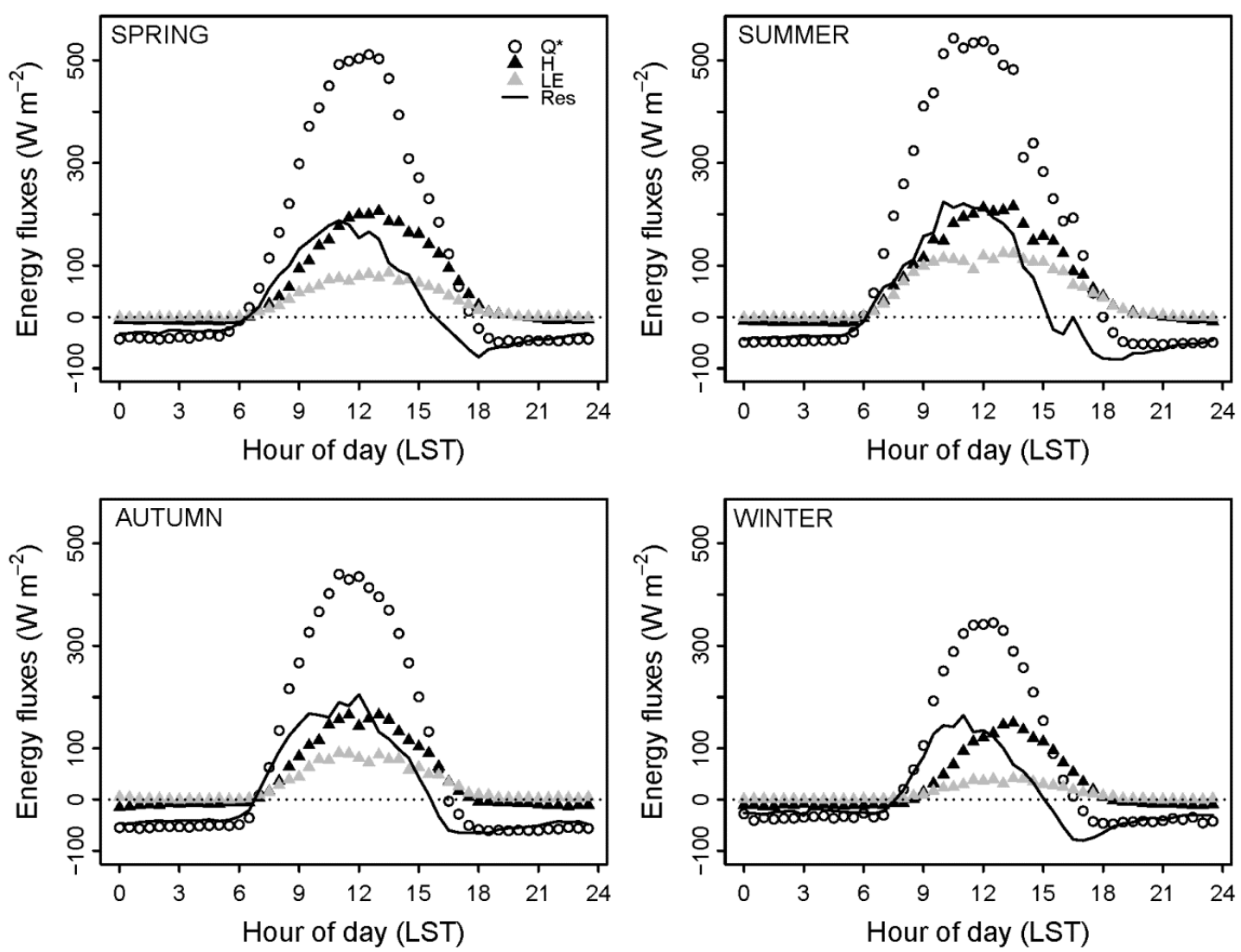

608

609

610

611

612

613

614

Figure 4. Comparative median diurnal variation of energy fluxes as a function of season. 

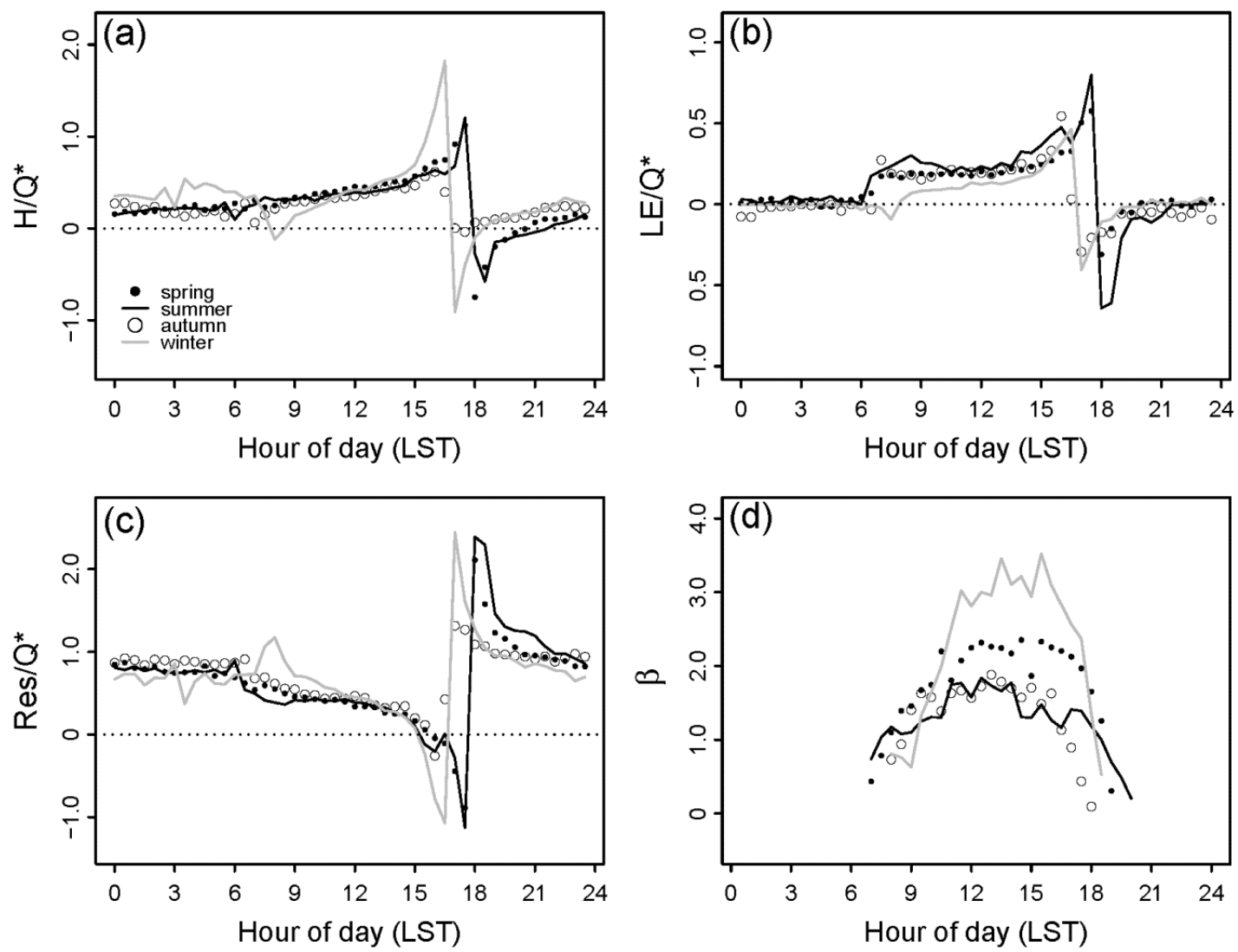

615

616

617

618

619

620

621

622
Figure 5. Median seasonal, diurnal variation of flux ratios: (a) $\mathrm{H} / Q^{*}$, (b) $\mathrm{LE} / Q^{*}$, (c) $\operatorname{Res} / Q^{*}$ and (d) $\beta$ $(=\mathrm{H} / \mathrm{LE})$. Bowen ratio in $(\mathrm{d})$ is drawn for daytime only $\left(Q^{*}>0\right)$ for each season. 

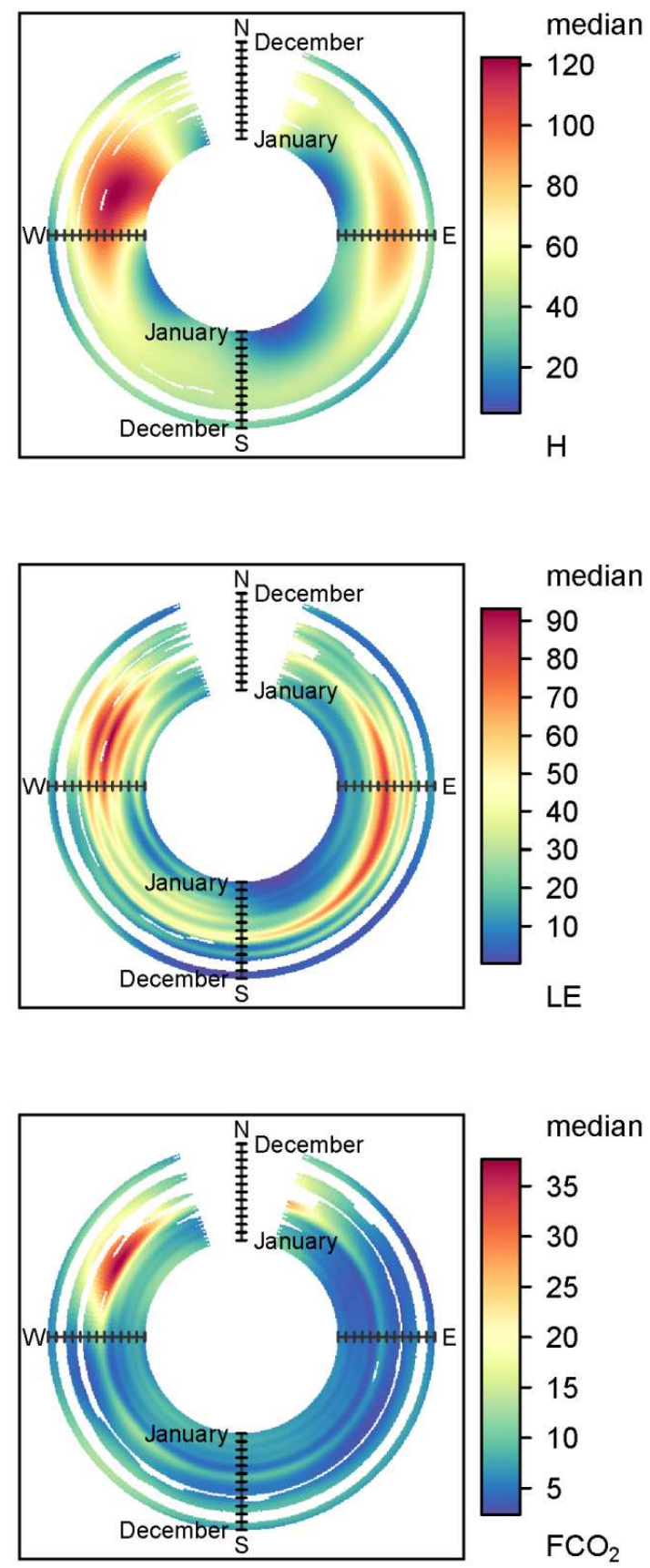

623

624

625

626
Figure 6. Monthly flux by wind direction of median $\mathrm{H}$ (top), $\mathrm{LE}$ (middle) and $\mathrm{CO}_{2}$ fluxes ( $\mu \mathrm{mol} \mathrm{m} \mathrm{s}^{-2} \mathrm{~s}^{-1}$ ) (bottom). The radial axis indicates the time of year (month). 

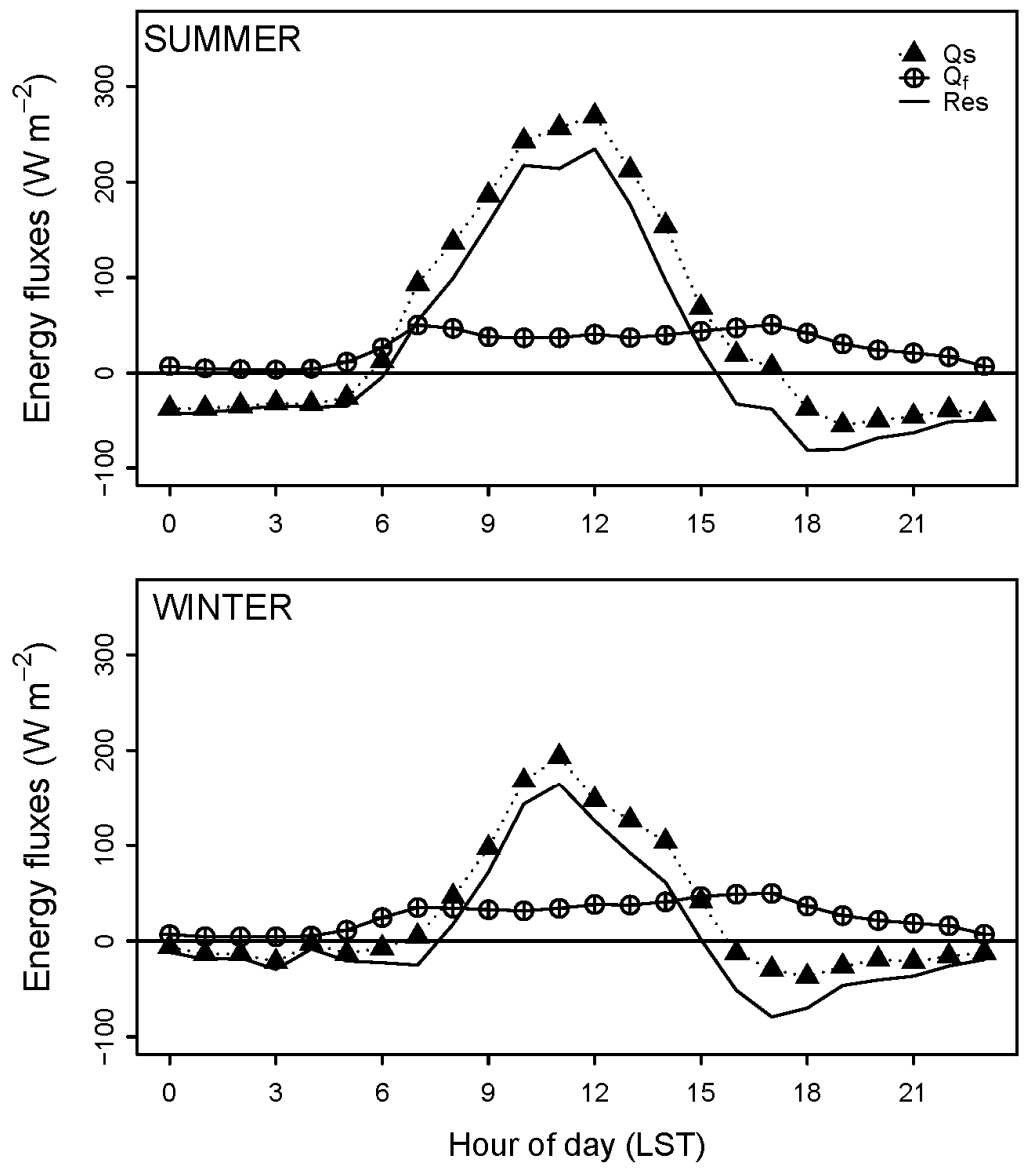

627

628

629

630

631

632

633

634

Figure 7. Calculated $\Delta Q s$ (black triangles) in summer and winter along with flux-weighted $Q_{f}$ (cross circle) and Res (black line). 


\section{Highlights}

- Seasonal energy flux measurements were conducted in a subtropical urban area

- Anthropogenic heat emissions were estimated via a residual method and an inventory

- Local anthropogenic heat sources were partially revealed

- A new "footprint-weighted inventory approach" was introduced 